\title{
Adjusting general legal rules to freedom of conscience: the Spanish approach
}

Javier Martínez-Torrón

\section{(2) OpenEdition}

1 Journals

Electronic version

URL: http://journals.openedition.org/rdr/299

DOI: $10.4000 /$ rdr.299

ISSN: 2534-7462

Publisher

Presses universitaires de Strasbourg

\section{Printed version}

Date of publication: 1 May 2019

Number of pages: 131-151

ISBN: 979-10-344-0045-4

ISSN: 2493-8637

Electronic reference

Javier Martínez-Torrón, « Adjusting general legal rules to freedom of conscience: the Spanish approach », Revue du droit des religions [Online], 7 | 2019, Online since 25 November 2019, connection on 21 November 2020. URL : http://journals.openedition.org/rdr/299; DOI : https://doi.org/10.4000/ rdr.299

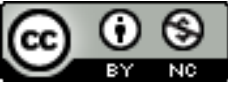

La revue du droit des religions est mise à disposition selon les termes de la Creative Commons Attribution - Pas d'Utilisation Commerciale 4.0 International - CC BY-NC 4.0. 


\section{ADJUSTING GENERALLEGAL RULESTOFREEDOM OFCONSCIENCE:THESPANISH APPROACH}

\section{Javier MARTÍNEZ-TORRÓN}

Universidad Complutense of Madrid

\section{Résumé}

L'adaptation des règles juridiques à l'objection de conscience est l'une des lacunes du système espagnol de garantie du droit à la liberté de religion ou de conviction. Au début des années 1980, la Cour constitutionnelle a adopté une attitude très favorable à la protection de cette liberté fondamentale, dans des arrêts concernant des objections au service militaire ou à l'avortement. Elle a choisi ensuite une position plus légaliste: l'accommodement ne serait possible que s'il est prévu par la législation. Cette jurisprudence, parfois incohérente, a influencé les tribunaux espagnols en faisant abstraction du principe de proportionnalité lors de l'appréciation de la nécessité de restreindre la liberté de conscience. Une telle position a un impact négatif sur les individus et les groupes qui sont en désaccord avec certaines des valeurs morales présentes dans la législation.

\section{Abstract}

The adjustment of legal rules to conscience claims is one of the shortcomings of the Spanish system of guarantee of the right to freedom of religion or belief. In the early 1980s, the Constitutional Court took a definite protective attitude in favor of that fundamental freedom, in judgments involving objection to military service or abortion. Shortly afterwards, however, the Court chose a more legalist position - accommodation of conscience would only be possible if foreseen and granted by legislation. Its case law, sometimes inconsistent, has influenced the Spanish courts by disregarding the principle of proportionality when assessing the necessity to restrict freedom of conscience. Such a position has a negative impact on individuals and groups that have a moral dissent with some of the moral values embedded in legislation. 


\section{CONFLICTS OF CONSCIENCE IN CONTEMPORARY SOCIETIES*}

In contemporary societies, there is an increasing need to find ways to accommodate freedom of religion or belief in many areas of public life. Or, to put it in other words, to find a solution for the problems that arise when there is a conflict between rules of general applicability and individual moral obligations deriving from the exercise of freedom of conscience, which is an aspect of freedom of religion or belief. ${ }^{1}$ This occurs in a variety of areas: from professional obligations imposed on health professionals (e.g., gynecologists, nurses or pharmacists) to the consequences of the religious observance of Sabbath, parents' objections to particular educational contents or practices, or the use of personal religious symbols in certain public spaces.

Conflicts of this type are more frequent today than in the past, especially in the West, because of several factors. One is the increasing religious and ideological pluralism of our societies. Another factor is the growing legislator's intervention in almost every area of social life; in Western societies the State is interventionist and omnipresent. In addition, our societies are also characterized, among other features, by a cultural climate that is highly permissive with regard to some ethical patterns and significantly rigid with regard to others (without providing always a clear and rational justification for that double standard). Such combination of elements is likely to produce areas of conflict in societies that tend to be more and more multi-religious, and in which there is an increasing development of individuals' atheistic and de-institutionalized moral attitudes.

Being conflicts between law and conscience not only diverse but also unpredictable, it is difficult to conceive that the legal system can efficiently and fairly address them exclusively through legislation or statutory law. This can - and must - be done with regard to the cases that have a substantial spread in society, and only to a limited extent, because it is utopian to think

This paper has been written in the context of the REVESTRA project (DER2015-64717-P). For the sake of brevity, I have reduced bibliographical references to a minimum and often refer to some of my previous works in which the appropriate references to legal literature can be found.

1. The following paragraphs are based on the author's ideas as expressed in J. MARTínezTORRÓN, "Conscientious objections: protecting freedom of conscience beyond prejudice", in S. FERrARi (ed.), Routledge Handbook on Law and Religion, Abingdon, Routledge, 2015, pp. 191-207. For a more developed explanation of those ideas, in the context of a wide comparative legal analysis, see R. NAVARRo-VALLS \& J. MARTínez-Torrón, Conflictos entre conciencia y ley. Las objeciones de conciencia, Madrid, Iustel, $2^{\text {nd }}$ ed. 2012. 
that a statute can foresee all possible circumstances in each type of conflict. Very often, a fair legal treatment of the problems derived from conflicts between law and conscience can be better achieved through the courts. With or without specific legislative regulation, only the courts can ultimately perform the individualized analysis that these cases demand.

On the other hand, there is little doubt that the issue of the accommodation of moral obligations must depart from the premise that the legal analysis of conflicts between law and conscience is directly linked to the human right to freedom of thought, conscience and religion, recognized by international instruments $^{2}$ and, with one or other terminology, by most world's constitutions. ${ }^{3}$ In this regard, it is important to emphasize that freedom of conscience does not consist only in the individual's right to choose the moral principles that guide his life. This freedom also entails the right to maintain behavior in conformity with the binding rules stemming from those moral choices, in ordinary as well as in extraordinary circumstances. And it is also important to note that, in order to render protection of freedom of conscience operative and efficient, we cannot extend the notion of conscience to any and every intellectual option inspired by personal views. It should be applied only to personal notions about moral right or wrong, i.e., the ensemble of supreme personal rules of conduct, rooted in religious or non-religious beliefs, which carry for the individual a weight that is more compelling than any other normative reference. ${ }^{4}$ For many people, living according to those moral principles is an essential element of their human dignity.

\section{LEGALISM VERSUS BALANCE OF INTERESTS}

However, as freedom of conscience is not an absolute right, the real challenge consists in determining its legitimate limitations when its exercise generates a situation in which there is an apparent incompatibility between some moral duties and some legal obligations derived from a general rule. Although this is certainly a complex issue, we can identify two basic legal approaches. One could be described as legalism and the other as balance of interests.

2. In Europe by the European Convention on Human Rights (Art. 9) and by the Charter of Fundamental Rights of the European Union (Art. 10).

3. See generally L. M. HAmmer, The International Human Right to Freedom of Conscience: Some Suggestions for its Development and Application, Aldershot, Ashgate, 2001; P. M. TAYLOR, Freedom of Religion: UN and European Human Rights Law and Practice, Cambridge University Press, 2005.

4. See K. Greenawalt, Conflicts of Law and Morality, New York, OUP/Clarendon Press, 1987, p. 26. 
The legalist perspective, frequent in the civil law tradition, assumes that every conflict between conscience and law - which is mainly understood as statutory law - must be resolved always in favor of the latter. Any other solution would imply a risk for juridical certainty. When a law is considered neutral - i.e., it pursues legitimate secular goals and is not intended against a particular belief or group of believers - freedom of conscience must yield, under the principle that the law is equal for all. The accommodation of religious or moral obligations is possible but only if explicitly foreseen and granted by legislation itself. This is so far, as explained below, the predominant perspective in Spanish law.

In contrast, the approach of the balance of interests proceeds originally from North-American law, which gives more significance to the role of the courts in the legal system. ${ }^{5}$ Its center of gravity is the search for the maximum possible degree of protection for freedom of thought, conscience and religion. As an Italian scholar put it long ago, being freedom of conscience a constitutional value in itself - and therefore a rule, not an exception to a rule - the adjustment of general legal rules to religious and moral obligations constitutes "a physiologic and not a traumatic" part of the legal dynamics in a democratic system. ${ }^{6}$ Therefore, when neutral legislation does not provide for an accommodation of conscience, the courts can impose such accommodation after a balancing process aimed at determining which legal interest deserves a prevailing protection. Such process, if done in a right way, should be done from a negative perspective. In other words, the crucial question is to ascertain which damage is worse for the legal system: the damage that would stem from encroaching a fundamental right of a citizen or a group of citizens (freedom of conscience); or the damage that granting the requested accommodation or exception would cause to the general legal interest pursued by the law in question.

In Europe, Article 10.2 of the Charter of Fundamental Rights of the European Union (CFREU) seems to support the balance of interests' approach

5. Among the immense US legal literature on the subject, see, from a historical perspective, M.W. McConnell, "The Origins and Historical Understanding of Free Exercise of Religion", Harvard Law Review, 103, 1990, pp. 1409-1517. The approach of the US Supreme Court, however, has experienced notable mutations - not always consistent - from the case law of the 1960s (Sherbert) to the turning point of Smith in the mid 1980s. In Spain, this issue has been studied in depth by J. I. RUBio LóPEZ, La primera de las libertades. La libertad religiosa en EE.UU. durante la corte Rehnquist (1986-2005): una libertad en tensión, Pamplona, Eunsa, 2006, pp. 319-377.

6. See R. Bertolino, L'obiezione di coscienza 'moderna'. Per una fondazione costituzionale del diritto di obiezione, Torino, Giappicchelli, 1994, p. 93. 
when providing - in general terms and not with reference to a particular type of objection - that "the right to conscientious objection is recognized, in accordance with the national laws governing the exercise of this right". It would be inaccurate to interpret the Charter's reference to national laws as subjecting the guarantee of conscientious objection to the condition of its prior recognition by ad hoc legislation. On the one hand, it would be unreasonable to make the existence and protection of a fundamental right in Europe dependent on the autonomous will of each national legislator. And on the other hand, if that were the case, it would not make any sense to include conscientious objection as a fundamental right in the CFREU. The Charter's reference to national laws should be construed as recognizing the national legislators' competence to regulate common types of conflicts between conscience and law, in order to facilitate their exercise and at the same time to make them compatible with the protection of other legal interests. In no case could it be understood as giving the legislator the prerogative of denying the existence of that fundamental right by merely not regulating it.

In my view, the balance of interests' approach, which requires a judgment of proportionality, is much more just. Of course the ideal would be that legislation itself provides for the accommodation of religious and moral obligations. But, if it does not, or does it insufficiently, the courts must be recognized the power to correct such deficiency in the protection of a fundamental right. Furthermore, legalism is based on a certain misrepresentation of reality; among other things, it ignores that the so-called neutral laws are actually not neutral at all. All laws, more or less visibly, are grounded on ethical values. Discarding the possibility of moral dissent curtails essential parts of the right to freedom of conscience and implies a form of ideological totalitarianism.

\section{FREEDOM OF CONSCIENCE IN THE SPANISH CONSTITUTIONAL COURT: ORIGINS AND EARLY CONTRADICTIONS}

Neither the Spanish Constitution (CE) nor the Organic Law on Religious Freedom of 1980 mention explicitly freedom of conscience, but it is usually deemed as implicitly recognized and protected by the Constitution. ${ }^{7}$ Indeed,

7. Among other reasons because Article 10.2 CE remits, for the interpretation of fundamental freedoms, to the Universal Declaration of Human Rights and to international treaties signed by Spain. As is well known, "freedom of thought, conscience and religion" is recognized by the UDHR (Art. 18), and guaranteed by the European Convention on Human Rights (Art. 9) and the International Covenant on Civil and Political Rights (Art. 18). 
the Spanish Constitutional Court has unambiguously held that freedom of conscience is protected by Article $16 \mathrm{CE},{ }^{8}$ and has been very clear in explaining that it "not only implies the right to form one's own conscience but also the right to act in accordance with its dictates". ${ }^{9}$ For the Constitutional Court, the State not only has a negative obligation not to interfere with individuals' decisions grounded on their moral convictions; it also has the positive obligation to protect "the exercise of that freedom against interference from other persons or social groups". ${ }^{10}$

This initial position of the Constitutional Court with regard to freedom of conscience, open and receptive, was maintained through the mid-1980s apropos of some early cases on various types of conscientious objection. Thus, in 1982, in one of its first decisions on conscientious objection to military service, the Court declared that there is a direct connection between conscientious objection and freedom of conscience, which is a particular aspect of the freedom of ideology enshrined in Article 16 CE. As the Court stated, conscientious objection is "a right recognized explicitly and implicitly in the Spanish constitutional order". ${ }^{11}$

A judgment of 1985 was even clearer in that direction. ${ }^{12}$ In addition to reaffirming that conscientious objection was intrinsically linked with freedom of conscience, the Constitutional Court emphasized that it was a right that could be exercised without the interpositio legislatoris. That is, its protection was not conditioned to the explicit support of an ad hoc legislative provision. The statement was made in the context of conscientious objection to abortion but the Court was intentionally expressing a doctrine of general applicability. ${ }^{13}$

8. See J. Martínez-Torrón, Religion and Law in Spain, Alphen aan den Rijn, Wolters-Kluwer, $2^{\text {nd }} \mathrm{ed}$. 2018, especially paras. 127-130. In this same book can be found a more extensive explanation of the ideas and case law mentioned in this paper.

9. STC 15/1982, FJ 6 [author's translations].

10. See ATC 617/1984, FJ 4; and ATC 551/1985, FJ 3.

11. See STC 15/1982, FJ 6.

12. STC 53/1985, FJ 14. For an analysis of this judicial doctrine in the light of comparative law, see R. NAVARRo-VAlLS, "La objeción de conciencia al aborto: derecho comparado y derecho español", Anuario de Derecho Eclesiástico del Estado, 2, 1986, pp. 257-310.

13. The Court had been asked to decide whether a statute decriminalizing some cases of abortion could be deemed unconstitutional because it did not contain any specific provision guaranteeing the conscientious objection of physicians and other healthcare personnel. The response of the Court was clear: strictly speaking a conscience clause was not needed because the Constitution itself protected conscientious objectors. 
Curiously enough, in another judgment delivered two months before, the same Constitutional Court adopted a totally different approach in a case concerning the right to observe the Sabbath rest. ${ }^{14}$ The plaintiff was a woman who, after converting to the Seventh-Day Adventist Church, had been dismissed for refusing to work on Saturdays - her company had rejected all the proposals she made in order to reconcile her work and her religious duties, including a change of shift and a reduction in her salary as compensation for her absence on Saturdays. The Court rejected the employee's claim with a reasoning that revolved around the secular character of Sundays as a common day of rest in contemporary Spain despite its religious origins. For the Court, changing the customary day of weekly rest was a possibility but not a duty that could be imposed unilaterally on the employer by the other party of the labor contract, not even for the protection of her freedom of conscience.

Remarkably, this judgment of the Constitutional Court focused almost completely on the analysis of the secular nature of Sundays as a common weekly day of rest instead of analyzing the central issue, namely if the employee's fundamental right to religious freedom generated any obligation of reasonable accommodation for the employer as far as it was not detrimental to the organization of work. In this regard, the Court refused to recognize such an obligation; indeed, the employer was not even obliged to justify his refusal to accept the alternative solutions proposed by the employee. In other words, the Court allowed the employer to treat the employee's request to rest on Saturdays for religious reasons as if it were grounded in any personal, trivial or whimsical motivation.

In a similar vein, the Constitutional Court kept a restrictive approach to the rights of individual conscience in two judgments of 1987 on the issue of conscientious objection to military service, which is explicitly recognized as an individual right by the Constitution. ${ }^{15}$ And the Court did it without overruling or nuancing its previous decisions. Beyond the holdings directly related to objection to military service, the most noteworthy aspect of the 1987 decisions is the restrictive concept of freedom of conscience they contain, in contradiction with applicable precedent. The Constitutional Court affirmed drastically that recognizing

14. STC 19/1985. For a critique to this decision, see A. CASTRO Jover, "Libertad religiosa y descanso semanal", Anuario de Derecho Eclesiástico del Estado, 6, 1990, pp. 299-312.

15. STC 160/1987 and STC 161/1987. These judgments decided, respectively, an appeal of unconstitutionality filed by the Spanish Ombudsman against the first laws that regulated conscientious objection to military service and the substitutive civil service; and a question of unconstitutionality filed by the National Court with regard to the same law. 
a general right to conscientious objection was unthinkable, for it "would imply denying the very idea of State". And the Court continued: "What can occur is that [conscientious objection] is exceptionally admitted with regard to a particular duty." 16 Thus, the Court tried to break the obvious link existing between conscientious objection and freedom of religion and belief, with the consequence that, without specific statutory support, there would not be any right to claim an exemption from or an adjustment of a legal obligation on moral or religious grounds, even under the umbrella of freedom of conscience. ${ }^{17}$

The contradictions inherent to this case law of the Constitutional Court can perhaps be explained, at least in part, by a contextualized interpretation. The judgment of 1985 would cover a broader spectrum of cases, as the Court unmistakably held that Article $16 \mathrm{CE}$ is sufficient to guarantee the rights of conscientious objectors and that no additional legislative provision is in rigor needed. Certainly, the Court did not intend to say that conscientious objection is an absolute or unconditional right. On the contrary, in its mention of Article $16 \mathrm{CE}$ there was an implicit reference to the constitutional limitations that can be legitimately imposed on freedom of conscience, as on any other fundamental right. And limitations on freedom of conscience are precisely what the Constitutional Court seemed to have in mind in its 1987 decisions. The Court's extreme assertion that a general recognition of conscientious objection "would imply denying the very idea of State" only makes sense if we understand it as related to a hypothetical recognition of that right in absolute terms, without any limitation whatsoever. The strong wording of the Court was likely caused by the fact that it was dealing with objection against a constitutional obligation - military service is mentioned in Article 30.1 CE as a "right and duty" of Spanish citizens - and not just against an obligation derived from an ordinary statute.

In sum, we could interpret that, while the 1985 broad recognition of conscientious objection would refer to a variety of areas in which freedom of conscience can be exercised, the restrictive interpretation of conscientious objection operated by the 1987 judgments would refer in particular to military service. ${ }^{18}$ Or perhaps these contradictory statements just suggest

16. STC 161/1987, FJ 3.

17. See also STC 160/1987, FJ 3.

18. In this respect, it is not unrealistic to presume that the Constitutional Court was in 1987 under the pressure of the fear of opening the way to an uncontrolled spread of conscientious objection, in the context of a European debate about the desirable profiles of the legal recognition of objection to military service, and also in the context of 
that the Court, rather than trying to clarify the rights of conscience, considered the "reasonability" of the claims of conscience - and, if that were the case, it would be a serious mistake, for in a neutral state public institutions are not entitled to judge which beliefs are reasonable and which others are not. ${ }^{19}$

\section{THE ERRATIC EVOLUTION OF THE CONSTITUTIONAL COURT'S CASE LAW: MEDICAL TREATMENTS, HOMESCHOOLING, ABORTION, AND PHARMACISTS}

Be that as it may, the doctrine of the Constitutional Court after 1987 has been far from uniform and clear on the issue of accommodating freedom of conscience.

Thus, in cases of objection to medical treatments the Court has sometimes been protective of freedom of conscience, even when there was a serious danger for a person's life. Two judgments of 1990 of the Constitutional Court marked the beginning of a new jurisprudential orientation in Spain in this area, although they did not concern directly freedom of conscience. The two cases involved hunger strikes commenced by members of a terrorist group while in prison. The Court stated, as an obiter dictum, that medical assistance would be illegitimate if forced on a person that has assumed the risk of death by a voluntary decision that is of his sole concern. In those particular cases, however, the Court justified the coercive feeding and medical treatment of the inmates to save their lives because public authorities have a specific responsibility towards people under their custody. ${ }^{20}$

In another decision of 2002, the Constitutional Court reiterated its position in favor of freedom of conscience apropos of another crucial question: if the parents incur criminal liability when a minor dies for lack of appropriate medical treatment. ${ }^{21}$ In that particular case, the parents of a 13-year-old boy - all of them active Jehovah's Witnesses - refused to try to persuade him to accept a blood transfusion that was needed as a consequence of an

a political debate about the role that the army should play in the evolution of the still incipient democracy in Spain.

19. This has been the definite position of the European Court of Human Rights since 1996 (see Manoussakis v. Greece, 26 Sept. 1996, para. 47).

20. See STC 137/1990, FJ 5 and STC 120/1990, FJ 7.

21. STC $154 / 2002$. 
accident - the patient became so horrified by the transfusion that the medical team considered it unviable to perform it in those conditions. The boy finally died, and it was deemed that, had the transfusion been performed timely, he would have had a 60 to $80 \%$ probability of recovery. The Constitutional Court declared the parents free from criminal liability, considering that parental custodial duties do not deprive parents from their right to religious freedom, especially when it was not their conduct that caused the boy's death and they never obstructed the medical procedures authorized by the judge. ${ }^{22}$

In an opposite direction, in 1996 the Constitutional Court held that the State has no economic responsibility if a Jehovah's Witness has sought, and successfully obtained, an alternative procedure to blood transfusions in a private hospital, when that alternative procedure had been previously denied to him by a public hospital. ${ }^{23}$ The Court refused to acknowledge any duty of accommodation and held that the State is not obliged to actively provide services to guarantee that believers can comply with their religious duties. For the Court, "Article 14 of the Constitution [principle of equality] recognizes the right not to be discriminated but not the hypothetical right to impose or demand differential treatment". ${ }^{24}$ This is a curious doctrine, indeed, especially if we consider that four years later the European Court of Human Rights (ECtHR) would hold just the opposite. ${ }^{25}$ It is therefore not surprising that one of the judges of the Constitutional Court wrote a dissenting opinion reminding that Article 9.2 CE provides that public authorities must facilitate the appropriate conditions to make fundamental freedoms "real and effective", which is especially applicable when the exercise of religious freedom does not contradict the lex artis of medicine, as proven by the fact that a private clinic could offer an alternative medical procedure that was compatible with the patient's religious beliefs.

The Constitutional Court has equally rejected that the State has any duty of accommodation in a very different realm: the parents' claim for the homeschooling of their children (which is unregulated in Spain). The

22. The circumstances of the case, which attracted much media attention, were more complicated than explained here. See, for further details, analysis and references, in addition to the works cited in notes 1 and 8, C. Molina, T. M. Pérez-Agua \& S. Siera, "Objeción de conciencia de un menor al tratamiento médico", Revista General de Derecho Canónico y Derecho Eclesiástico del Estado, 6, 2004, pp. 1-50; M. CebriÁ, Objeciones de conciencia a intervenciones médicas, Pamplona, Aranzadi, p. 72 ff.

23. See STC 166/1996.

24. Ibid., FJ 5.

25. See Thlimmenos v. Greece, 6 April 2000, para. 44. 
Court has adjudicated twice on this issue. The first decision, in 1994, is not very relevant, for it involved very specific circumstances of children of members of an atypical religious movement (The Children of God) who were almost completely separated from the surrounding social environment. ${ }^{26}$ The second decision, in 2010, ${ }^{27}$ is much more significant and was influenced by the Strasbourg case law. ${ }^{28}$ The Constitutional Court rejected the claim of some parents, homeschoolers, who had been judicially urged to send their children to school. Their objection to ordinary schooling was not based on religious grounds but on their profound disagreement with the pedagogical model that inspired Spanish compulsory education. On the basis that the legislator could impose mandatory schooling for a specific range of ages, the Court denied that parents had any right to homeschool their children in the absence of an explicit legislative provision permitting it, even in the hypothesis that their objection would have been grounded on religious or moral reasons. As in other occasions, any serious analysis of proportionality or balance of interests was absent in the Court's reasoning.

In the area of objection to abortion, the above-mentioned clear doctrine of the Constitutional Court in 1985 in favor of accommodating the freedom of conscience of healthcare professionals was undermined by a 2010 statute on abortion. ${ }^{29}$ Article 19.2 of that statute introduced a conscience clause, apparently more concerned about restricting health professionals' freedom of conscience than about guaranteeing it. ${ }^{30}$ Among other things, the law emphasizes that "access to and the functional quality of the service cannot be impaired by the exercise of conscientious objection", and provides that objections "must be expressed in advance and in writing".

In 2014, the Constitutional Court decided an appeal of unconstitutionality against a regional law of the region of Navarra that created a registry of

26. See STC 260/1994.

27. STC 133/2010. For a critical view of this judgment, see M.J. VALERO, "Homeschooling en España. Una reflexión acerca del artículo 27.3 de la Constitución y del derecho de los padres a elegir la educación de sus hijos", Revista General de Derecho Canónico y Derecho Eclesiástico del Estado, 28, 2012, pp. 1-32.

28. See Konrad and others v. Germany, decision on the admissibility of Appl. Nr. 35504/03, 11 Sept. 2006, in which the Court followed the criteria formerly proposed by the European Commission of Human Rights in Leuffen v. Germany, decision on the admissibility of Appl. Nr. 19844/92, 9 July 1992.

29. Ley Orgánica 2/2010, 3 March 2010, de salud sexual y reproductiva y de la interrupción voluntaria del embarazo.

30. Indeed, the conscience clause is within Article 19, whose title is "measures to guarantee the performance [of abortion] by health services". 
conscientious objectors. ${ }^{31}$ The Court sustained the constitutionality of the law, whose declared aim was to facilitate the organization of public hospitals and ensure that pregnant women wishing an abortion could have it performed. For the Constitutional Court, the law was a proportionate limitation on the procedural, not the substantial, aspects of freedom of conscience, especially considering that the law guaranteed the confidentiality of the data given by the people who would register as objectors. One of the judges wrote a strong dissenting opinion noting that the experience of the time in which the law had been in force demonstrated that it had a powerful dissuasive impact on conscientious objection in that part of Spain - prior to the law there was a massive objection among health professionals, and four years after the registry was created only one gynecologist had registered as objector. This, in the dissenting judge's opinion, revealed that the fear of discrimination was real and that the effect of the law went beyond the mere procedure and touched on the very substance of freedom of conscience.

In any event, beyond the particular case of this regional registry, the need to respect the freedom of conscience of health professionals refusing to take part in the performance of an abortion is well rooted in the Constitutional Court's case law. This doctrine is so embedded that its shadow has influenced - and not necessarily in a positive way - the Court's analysis of other cases in the area of health services, such as the conscientious objection of pharmacists to sell contraceptive products.

In 2015, the Constitutional Court adjudicated on the appeal of a pharmacist of a big city (Seville) that refused to store and sell in his pharmacy the morning-after pill (Levonorgestrel) as well as contraceptive devices, in contravention of the regional laws of the region of Andalusia. ${ }^{32}$ He was fined for that reason, following a routine inspection performed by a public official. The Court recognized the right to conscientious objection against selling Levonorgestrel taking into account that this chemical may have abortive effects. The Court's reasoning was that, if its previous case law had unequivocally recognized the right to object to abortion on moral grounds (in 1985), the pharmacist's objection was a legitimate consequence of the exercise of his freedom of conscience (especially in the case of a city

31. STC 151/2014. For a critical comment, see R. NAVARRO-VALLS, "Una ocasión perdida. Comentario a la STC de 23 de septiembre de 2014, sobre registro de objetores de conciencia al aborto", Revista General de Derecho Canónico y Derecho Eclesiástico del Estado, 36, 2014, pp. 1-7.

32. STC $145 / 2015$. 
as Seville, where pharmacies are abundant and easily accessible, so that the rights of no potential buyers were actually harmed). However, when it came to the plaintiff's objection to sell condoms, the Court did not even enter into the merits of the claim and, without further explanation, simply declared that "it does not raise any conflict of conscience of constitutional significance". ${ }^{33}$ It looks like the Constitutional Court adjudicated this case moved by respect to precedent, but it was not prepared to analyze seriously a new situation of accommodation of conscience in the area of health services.

\section{LEGISLATION AND CASE LAW OF OTHER SPANISH COURTS}

The case law of other Spanish courts, as well as legislation, has been influenced by the aforementioned irregular and inconsistent approach of the Constitutional Court in cases in which accommodation of freedom of conscience was on the table. For the sake of brevity, I will focus here on two areas: labor relations and religious symbols in the public space.

\subsection{LABOR RELATIONS}

In 1992 the Spanish State concluded, and approved by parliamentary statute, three cooperation agreements with three federations, respectively, of Evangelical, Jewish, and Muslim communities. ${ }^{34}$ Article 12 of those agreements faces the issue of religious rest on Saturdays and other holy days for Jews, Seventh-Day Adventists and members of other Evangelical churches, as well as Muslims' obligation of observing the collective prayer on Fridays and the Ramadan fast. Strictly speaking, this article does not recognize or guarantee any individual right on this aspect of religious observance. It just foresees the possibility of accommodating the religious duties of Jewish, Evangelical or Muslim employees, provided that there is an agreement between the two parties of the labor contract.

This means that the employer has, in practice, unlimited discretion to accept or reject the requests of his employees for religious observance.

33. See, for a critical analysis of this judgment's rationale, J. MARTínEz-TorRón, "La objeción de conciencia farmacéutica en la reciente jurisprudencia constitucional española: otra oportunidad perdida", Revista General de Derecho Canónico y Derecho Eclesiástico del Estado, 39, 2015, pp. 1-29.

34. For a further explanation of those agreements I refer the reader to J. MARTínEZ-TorRón, Religion and Law in Spain, cited in note 8, paras. 70-72 and 354-360. 
No obligation to justify his denial of those requests, or to search for a reasonable accommodation of the employee's religious duties, is imposed on the employer. Moreover, the 1992 agreements do not distinguish between labor relationships with private employers and with public agencies or companies. Not surprisingly, this article has been criticized not only for being redundant but also for containing a restrictive interpretation of the religious freedom protected by the Constitution, the Organic Law on Religious Freedom and the Statute of Workers, whose Article 17.1 specifically forbids indirect discrimination - a notion that should be interpreted in the light of the European Union's Council Directive 2000/78/EC.

Interestingly, the reason of this restrictive interpretation of the employee's religious freedom is to be found in an opinion delivered by the Council of State in 1991 on the drafts of the three cooperation agreements. The drafts, following the example of the Italian cooperation agreements (intese), recognized employees a proper right to religious observance, provided that it was compatible with the employer's organization and with the maintenance of minimum services. The Council of State, however, held the view - wrongly, in my opinion - that the above-mentioned judgment of the Constitutional Court of $1985^{35}$ made it necessary to modify the drafts of the agreements and give virtually all discretion to the employer. Its opinion prevailed in the elaboration of the final text. And I say that the Council of State's opinion was wrong because one thing is to acknowledge that the Constitutional Court refuses to recognize that the employer has any duty of accommodation in the absence of a specific contractual clause or legislative provision; and a very different thing is to say that the legislator cannot approve a rule that precisely imposes such duty of accommodation on the employer. The latter statement cannot be found anywhere in the Constitutional Court's judgment of 1985.

A similar lack of sensitivity to employees' freedom of conscience and to the notion of indirect discrimination can be seen in a different type of claim, decided by the Superior Court of Justice of Madrid in 1997.36 The plaintiff was a Muslim female employed by the company that manages the duty-free shops in the Madrid airport. After three weeks at work, she made a written request asking for some specific working conditions in order to reconcile her job with her religious beliefs. In particular, she asked to be exempted from the obligation to wear a short skirt (the company's rules on

35. See supra, note 14 and accompanying text.

36. STSJ Madrid (Sala de lo Social, sección 5a), 27 Oct. 1997 (AS 1997/3751). 
uniform prescribed a skirt above the knees); to be authorized to leave the working place for three hours on Fridays for the collective prayer; and to be excused from working at sections where she had to handle pork or alcoholic products. The management rejected all her requests, and the Court confirmed the employer's position with a reasoning in which, once again, there was not even the shadow of a reference to indirect discrimination, reasonable accommodation, proportionality, or balance of interests. On the contrary, the judgment emphasized that the employee, as a manifestation of "loyalty and good faith", should have declared her religious beliefs and explained her requests when applying for the job, in order to let the employer decide if they were compatible with its organizational needs.

In subsequent years, however, some Spanish courts have adopted a more protective approach to the employee's freedom of conscience, at least with respect to the use of religious symbols in the workplace. In 2002, the Superior Court of Justice of Baleares ${ }^{37}$ decided a case involving a Jewish bus driver who worked for a municipal transportation service. After several years wearing a cap at work on religious grounds, as a sign of respect for God, the company sanctioned him for not complying with the rules on uniform. The Court ruled in favor of the employee, noting that the employer's right to impose a uniform at work was not unlimited, for it may collide with fundamental rights of the employees, such as religious freedom. The Court did perform an analysis of proportionality based on the existence of an implicit duty of accommodation on the part of the employer. For the Court, the employer's position could be sustained only if his legitimate interests were harmed by the employee's religiously motivated behavior. In this case, the Court concluded that there was no such harm - indeed, the employer had not even hinted at such possibility when arguing at trial. The Court added another interesting nuance: the need to differentiate between public and private employers when it came to accommodating the obligations of conscience of their employees. Sanctioning an employee because of a harmless expression of religiosity was even less acceptable in the case of a municipal company, which, being part of the public sector, should be especially committed to constitutional rights and values.

In the same region of Baleares, an employment court of first instance (in Mallorca) decided another case, in 2017, in favor of a broad protection of religious freedom. ${ }^{38}$ The case concerned a female Muslim employee of a

37. STSJ Baleares 457/2002 (Sala de lo Social, sección 1a), 9 Sept. 2002.

38. Juzgado de lo Social $n^{\circ} 1$ of Palma de Mallorca, judgment 31/2017, 6 Febr. 2017. 
handling company at the airport of Palma de Mallorca, who was prohibited from wearing her hijab at work and sanctioned because of her refusal to comply. The company alleged the contractual rules on the employees' uniform, which in its opinion contained a closed list of wearable items. The Court decided in favor of the employee, arguing on the basis of the Spanish Constitution, the EU law (especially the Council Directive 2000/78/EC), the ECHR and the case law of the Strasbourg Court (especially Eweida). ${ }^{39}$ In the Court's view, the employer had treated the employee's hijab as a mere decorative garment and ignored its religious dimension, thus failing to make any effort to adjust the general rules on uniform to the plaintiff's religious freedom. The Court also noted that the rules on uniform did not contain any prohibition of Islamic headscarves, that the company did not have any specific policy of religious neutrality, ${ }^{40}$ and that other employees were permitted to wear crosses, piercings or tattoos in apparent contraventions of uniform rules without any reaction from the company's management. Considering that the employee did not intend to substantially alter her employment contract but just to observe what she considered an important moral obligation in exercise of a constitutional freedom, the Court concluded that she had been discriminated on the ground of her religious beliefs.

\subsection{RELIGIOUS SYMBOLS IN THE PUBLIC SPACE}

In the school environment, unlike what has occurred in other European countries, there have not been, so far, significant problems in Spain with the wearing of religious garments, and in particular Islamic headscarves. ${ }^{41}$ In Spain there is no national or regional legislation on the issue of religious clothing in public schools and therefore its regulation is in the hands of the school boards. Normally, the internal rules of schools refer to clothing in general rather than to religious garments in particular, and tend to be applied with flexibility. By and large, in public schools there is an atmosphere of tolerance of religious symbols of any kind, including Islamic clothing.

39. Eweida and others v. United Kingdom, 15 Jan. 2013.

40. Compare this part of the court's reasoning with the judgment of the EU Court of Justice Bougnaoui v. Micropole SA, C-188/15, 14 March 2017.

41. More conflicts have been taken to the courts concerning the open display of Christian symbols in public schools and other public places. I refer the reader, for the relevant case law and legal literature, to J. MARTínez-TORrón, Religion and Law in Spain, cited in note 8 , paras. 214-221. 
As far as I know, there have been only two reported cases, both of them in the region of Madrid, which gathers a high percentage of the Muslim population of Spain. The first one dates back to 2002 and involved a 13-year-old Moroccan student that remained several months without schooling because the Catholic school (State funded) in which she studied prohibited the use of hijab, by reason both of its religious ethos and its rules on the students' uniform. As neither the student's parents nor the school would make their respective positions more flexible, regional public authorities found a practical solution consisting in transferring the student to a nearby public school where such prohibition did not exist. ${ }^{42}$

The second case, in 2010, generated a much more intense attention from the media as well as a judicial decision. The problem arose when the board of a public school in a town near Madrid forbade a young Muslim student, 16-year-old, to wear her hijab, in a strict interpretation of the internal regulations that vetoed the use of "caps or any other head-covering garment" while in school. The school board sanctioned the student with a written warning for disobeying the school rules, ignoring the fact that the internal rules also mentioned that the students' rights included respect for their "identity and moral integrity and dignity", as well as respect for their "freedom of conscience, religious and moral convictions". The student ended up registering in other nearby public school where she could wear her hijab without objection. At the same time, her father initiated an administrative review procedure and later a judicial procedure against the school sanction.

In 2012, a court of first instance rejected his claim ${ }^{43}$ with a poorly reasoned judgment that justified the school board's position by reference to the European Court's case law, indicating that the board was free to interpret the notion of public order as excluding the use of veils. ${ }^{44}$ Once again, any analysis of the proportionality of the measure vis-à-vis the student's freedom

42. See S. Cañamares ARribas, "Tratamiento de la simbología religiosa en el Derecho español: propuestas ante la reforma de la Ley orgánica de libertad religiosa", Revista General de Derecho Canónico y Derecho Eclesiástico del Estado, 19, 2009, pp. 7-9.

43. See Juzgado Contencioso Administrativo Nr. 32 of Madrid, Judgment Nr. 35/2012, 25 Jan. 2012. Confirmed by STSJ Madrid 129/2013 (Sala de lo Contencioso-Administrativo), 8 Febr. 2013.

44. The decisions of the ECtHR cited by the judgment of the Madrid court are Dogru, Kervanci and Dahlab, which are not, in the view of many scholars, particularly good examples of interpretation of Art. 9 ECHR. See, for a critical analysis of those and other ECtHR's decisions concerning the wearing of hijab, J. MARTínEZ-TORRÓN, "Islam in Strasbourg: Can Politics Substitute for Law?", in W. C. Durham, D. M. Kirkham, C. Scott \& R. Torfs (eds), Islam, Europe and Emerging Legal Issues, Farnham, Ashgate, 2012, pp. 49-59. 
of conscience was absent. It is worth noting that, when the Muslim student was looking for a new school to register, a nearby public school modified its internal rules, through an urgent procedure, to ban the use of headcovering garments. For those of us who think that limitations on religious freedom must be grounded on consistent and concrete arguments, and not just on vague references to general concepts, this fact reveals that a more accurate regulation of the wearing of religious symbols at school is needed at a national level, in order to adequately protect the student's freedom of conscience against arbitrary restrictive measures.

If we look out of the school environment, Spanish regulation of religious clothing has been in general quite flexible at a national level, trying to reconcile the interests of public security and the citizens' freedom of conscience. Thus, the rules on the application for identification documents permit that applicants provide personal photographs wearing a hijab and most common religious garments, provided that the oval of the face is entirely visible. Obviously, a photo with a burka or niqab would not be acceptable. ${ }^{45}$

In Spain, in recent years, the use of burka or niqab in public places has become a controversial question, as in other European countries, but it has not led to national legislation similar to that of France or Belgium. ${ }^{46}$ However, at a local level, in the early 2010s, several city councils in the region of Catalonia - including three of the four provincial capitals: Barcelona, Tarragona and Lérida - enacted municipal ordinances prohibiting the use of full veil in municipal facilities. ${ }^{47}$ In 2011, the Superior Court of Justice of Catalonia rejected a judicial appeal against the ordinance of Lérida. ${ }^{48}$ The Court sustained the validity of the ordinance, holding that reasons of public order justified its negative impact on the religious freedom of some citizens. In particular, the Court mentioned: the connection between visual identification of people and public security in public facilities; and the fact that hiding one's face in daily life caused anxiety and worry in surrounding people, except when it was required by the weather or by the

45. See, for the relevant legal references, J. MARTínez-Torrón, Religion and Law in Spain, cited in note 8, paras. 206-207.

46. The issue of full veil in Spain, from a comparative perspective, has been analysed in detail by V. CAMARERo, El velo integral y su respuesta en democracias europeas, Valencia, Tirant Lo Blanch, 2012. See also R. NAvarro-Valls \& J. Martínez-Torrón, Conflictos entre conciencia y ley, cited in note 1, pp. 378-384.

47. Precise references can be found in V. Camarero, El velo integral..., cited in the previous note.

48. STSJ Cataluña 489/2011 (Sala de lo Contencioso-Administrativo, Sección 2a), 7 June 2011. 
performance of certain jobs (the implicit message, therefore, was that social opinion or cold weather are more important than freedom of religion for the organization of the public space). The Court also indicated that the use of burka or similar garment, which is done exclusively by women, was not compatible with the principle of equality between men and women, even if the latter wear it voluntarily.

The Supreme Court overruled that decision in a judgment of $2013^{49}$ and declared the ordinance of Lérida null and void for violation of the freedom of religion protected by Article $16 \mathrm{CE}$. The Court's rationale focused on the lack of competence of city councils to regulate fundamental rights guaranteed by the Constitution. The Supreme Court held that, in the absence of a prior ad hoc legislation, municipal by-laws prohibiting the use of garments that constitute a manifestation of religion imposed a limitation on religious freedom and had to be considered invalid. ${ }^{50}$ The Supreme Court also rejected the argument of the inferior court based on the equality between men and women, considering that there was no sufficient evidence to sustain that public peace was disturbed by people hiding their faces. The Supreme Court's doctrine has had an impact on the case law of the Superior Court of Catalonia, which in 2015 suspended the enforcement of an anti-burka municipal ordinance of another town. ${ }^{51}$

It should be noted that the Supreme Court's judgment pivoted around on the lack of legal competences of city councils to regulate fundamental freedoms (Art. 53.1 CE), and it explicitly made clear that the legislator was competent to impose limitations on the use of full veil, if it considered it appropriate. The Court also stated that this judgment should not be interpreted as an attempt to condition the choices available to Parliament, for that would be an "unacceptable interference" with the legislator's competences. However, so far neither the national parliament nor regional legislatures have enacted such legislation on the full veil, and it does not seem likely that they will do so in the next future.

49. STS 693/2013, 14 Febr. 2013.

50. The Supreme Court mentioned one exception to this limitation on municipal competences, namely the regulation of the city public transportation service, which requires the identification of passengers with personal cards that permit the use of public transportation at a reduced price.

51. ATSJ Cataluña 1/2015 (Sala de lo Contencioso-Administrativo, Sección 5a), 29 Jan. 2015. 


\section{CONCLUDING REMARKS}

When dealing with situations derived from the need to accommodate claims of conscience in the public space or in the workplace, the Spanish Constitutional Court is reluctant to accept the possibility of imposing such accommodation unless the legislator has explicitly foreseen and regulated it. The conscientious objection to abortion of health professionals is the only clear exception to that tendency. This restrictive position is difficult to understand, for there is a well-established case law of the same Constitutional Court holding that the Constitution is directly applicable. Consequently, the constitutional provisions that guarantee fundamental rights - and therefore freedom of conscience - can and must be used to solve legal conflicts, irrespective of whether there is or not an interpositio legislatoris, i.e., a specific provision of an ordinary statute foreseeing that a fundamental right shall be protected in a concrete type of situation. ${ }^{52}$

The Constitutional Court's legalist approach has often influenced the position of other Spanish courts. Due to space constraints, I could not mention in this paper other cases that are expressive of that position; for instance, in the realm of education, where we find a notable unwillingness of the courts to provide for any accommodation of parents', and their children's, freedom of conscience when they have serious moral scruples against some educational contents or practices. The most well-known example is the case law of the Supreme Court, in 2009, on the conscientious objection against the school subject called "Education for Citizenship", which raised a huge controversy in Spain some years ago because some of its contents went beyond what is usual in Europe in this type of courses and invaded the domain of private ethics, in which a neutral state should have no saying. The Supreme Court was strongly divided, but the legalist approach prevailed among the majority of judges, with a reasoning that even rejected the applicability of the Strasbourg Court's doctrine on the parents' rights in the judgments Folgerø and Zengin. ${ }^{53}$

52. As the Constitutional Court put it in STC 53/1985, FJ 14: "The right to conscientious objection [...] exists and can be exercised irrespective of the fact that it has been regulated by a statute or not. Conscientious objection is an integral part of the fundamental right to freedom of ideology and religion, recognized in Article 16.1 of the Constitution; and, as this Court has repeatedly indicated, the Constitution can be directly applied, especially when fundamental rights are concerned."

53. Folgerø v. Norway, 29 June 2007, and Zengin v. Turkey, 9 Oct. 2007. There is a vast legal literature in Spain about this controversial case law. Perhaps the best explanation and analysis of it and its context can be found in two works of L. RUANO EsPINA: "Objeción de conciencia a la Educación para la Ciudadanía", Revista General de Derecho Canónico 
Those decisions of the Supreme Court reveal a pattern that, unfortunately, has become usual in Spanish courts, with few exceptions: an almost total deference to the legislator's discretion that leads the Court to excuse itself from engaging in any serious proportionality analysis of the conflicting interests. Very often, the courts limit themselves to ascertain the existence of a public interest that inspires the relevant legislation, and to reiterate the legislator's competence to rule on the consequences of that public interest, even when it clearly impinges on freedom of conscience.

The big challenge in Spain, therefore, at all judicial levels, is to take seriously the principle of proportionality. This requires, first, an unequivocal recognition that freedom of conscience protects in principle the right of all persons to conduct their life in accordance with their own religious and moral rules; and second, that the courts demand public authorities to prove that denying the requested accommodation of individuals' conscience is "necessary in a democratic society" (Art. 9.2 ECHR), and not merely convenient, useful or practical.

The accommodation of freedom of conscience in contemporary societies is more needed than ever, not only because we are supposed to look actively for the maximum degree of protection of fundamental rights but also because we live in social communities with an increasing degree of religious and ideological pluralism. What is at stake is a fundamental right, indispensable for a free and equitable society - freedom of conscience is not a private interest of the individual, it is a paramount public interest whose guarantee, or lack of guarantee, will have repercussions in the entire social dynamics.

And what is also at stake is the protection of religious minorities. The so-called neutral laws are not so neutral. All laws rest on ethical foundations, more or less explicit, which normally depend on the majority values present in a given society. This is the reason why the conflicts of conscience caused by neutral laws usually involve people in minority positions. To affirm the absolute predominance of neutral legal norms, and to discard the need for an accommodation of freedom of conscience implies, de facto, a potential discrimination not only against individuals but also against religious minorities that do not share the underlying values adopted by the majority.

y Derecho Eclesiástico del Estado, 17, 2008, pp. 1-61; and "Las sentencias del Tribunal Supremo de 11 febrero 2009 sobre objeción de conciencia a EpC", Revista General de Derecho Canónico y Derecho Eclesiástico del Estado, 19, 2009, pp. 1-60. See, for further references, the works cited in notes 1 and 8 . 